\title{
Detection of Circulating Gastrointestinal Cancer Cells in Conditionally Reprogrammed Cell Culture
}

\author{
CHUN-SEOK YANG ${ }^{1}$, IN-HWAN KIM ${ }^{1}$, HYUN-DONG CHAE $^{1}$, DAE-DONG KIM ${ }^{2}$ and CHANG-HO JEON ${ }^{3}$ \\ ${ }^{1}$ Department of General Surgery, Medical School, \\ Daegu Catholic University Medical Center, Daegu, Republic of Korea; \\ ${ }^{2}$ Department of General Surgery, Medical School, Yonsei University, Seoul, Republic of Korea; \\ ${ }^{3}$ Department of Laboratory Medicine, Medical School, \\ Daegu Catholic University Medical Center, Daegu, Republic of Korea
}

\begin{abstract}
Background/Aim: The aim of this study was to detect circulating tumor cells (CTC) in the peripheral blood of gastrointestinal cancer patients using conditionally reprogrammed cell (CRC) culture. Materials and Methods: We confirmed the sensitivity of the CRC culture method. Five $\mathrm{ml}$ of blood were obtained from 81 cancer patients (56 colorectal and 25 gastric). The collected mononuclear cells were cultured for 4 weeks in the CRC condition. Finally, cultured cells were characterized by RT-PCR for the expression of hTERT and MAGE A1-6 mRNA. Results: The CRC method had a CTC detection limit of 6 cells for gastric cancer cells. After culture of 81 blood specimens, 38 formed visible cells, including 5 colonies. Among the 38 cells, 13 were hTERT positive and 4 were MAGE Al-6 positive. The final CTC detection rate was $16.0 \%$. Conclusion: The CRC culture may potentially be used to evaluate the metastatic cancer cells in the circulation.
\end{abstract}

Detection of circulating tumor cells (CTCs) in the blood has been investigated using various methods based on antibodies, transcripts or proteins $(1,2)$. Recently, many researchers utilized cell-free DNA (cfDNA) instead of CTCs (3-5). Regarding some solid tumors, cfDNA has produced promising results (6). However, the approach is limited because cfDNA yields the same information regarding mutations and epigenetic modifications as the tumor tissue

This article is freely accessible online.

Correspondence to: Chang-Ho Jeon, Department of Laboratory Medicine, Medical School, Daegu Catholic University Medical Center, 33 Duryugongwon-Ro 17-Gil Namgu, Daegu, 42732, Republic of Korea. Tel: +82 1038111034, e-mail: chjeon@cu.ac.kr

Key Words: Blood, neoplasm, culture, reverse transcription, hTERT, MAGE. without providing any information about protein and RNA transcription profiles of the tumor phenotype (7).

The detection of CTCs has been refined by the progression from the conventional immunologic capture method using EpCAM and cytokeratin antibody to an in vitro cell culture method $(8,9)$. CTC culture consists of short-term culture, such as the epithelial immunospot approach, and long-term culture (1). Successful culture rates for patients with early lung cancer have been achieved using a three-dimensional co-culture system (10). However, CTC cultures for gastrointestinal cancers are rare (11-14).

The Georgetown University Medical Center (GUMC) has also developed a conditionally reprogrammed cell (CRC) culture method using 3T3 mouse fibroblasts (J2 cells) and a Rho-kinase inhibitor (Y27632) (15). The CRC culture method is very efficient for the culture of tumor cells in vitro.

In this study, we attempted to detect circulating colorectal and gastric cancer cells using the CRC culture. To characterize the cultured cells isolated from the peripheral blood, we used the Melanoma antigen-encoding gene $(M A G E)$ and human telomerase reverse transcriptase ( $h T E R T)$ mRNA as markers. MAGE is known to be a cancerspecific gene, but individual $M A G E$ genes are poorly expressed in cancer cells $(16,17)$. Common MAGE primers that can detect MAGE A1 to A6 (MAGE A1-6) mRNA simultaneously were developed and have been used in various types of cancer $(18,19)$. The hTERT mRNA has also been studied in many types of cancer cells (20). Though the hTERT mRNA would be also expressed in activated lymphocytes (21), it has been utilized as a sensitive and specific tumor marker in the blood.

\section{Materials and Methods}

Sensitivity of CRC technique. To confirm the sensitivity of the CRC technique, we used SNU484 gastric cancer cells obtained from the Korean Cell Line Bank (Seoul, Republic of Korea), and colorectal 
Table I. Gene-specific primers used in the polymerase chain reactions.

\begin{tabular}{|c|c|c|c|c|}
\hline Gene & Sequences & Products & $\mathrm{Ta}\left({ }^{\circ} \mathrm{C}\right)$ & Cycles \\
\hline \multirow[t]{2}{*}{ MAGE A1-6 } & $\begin{array}{l}\text { OF 5'-CTG AAG GAG AAG ATC TGC C } \\
\text { OR 5'-CCA GCA TTT CTG CCT TTG TGA }\end{array}$ & $465 \mathrm{bp}$ & 60 & 30 \\
\hline & $\begin{array}{l}\text { IF 5'-AAG GAG AAG ATC TGC CAG TG } \\
\text { IR 5'-GAG GCT CCC TGA GGA CTC T }\end{array}$ & $262 \mathrm{bp}$ & 62 & 25 \\
\hline \multirow[t]{2}{*}{ hTERT } & $\begin{array}{c}\text { OF 5-CGG GCT GCT CCT GCG TTT GGT G } \\
\text { OR 5'-AGC CGC GGT TGA AGG TGA GAC TGG }\end{array}$ & $311 \mathrm{bp}$ & 68 & 30 \\
\hline & $\begin{array}{l}\text { IF 5'-TCA CCT CAC CCA CGC GAA AAC CTT } \\
\text { IR 5'-CGT GGG CCG GCA TCT GAA CAA A }\end{array}$ & $152 \mathrm{bp}$ & 66 & 25 \\
\hline GAPDH & $\begin{array}{l}\text { OF 5'-TCG GAG TCA ACG GAT TTG GTC GTA } \\
\text { OR 5'-CAA ATG AGC CCC AGC CTT CTC CA }\end{array}$ & $320 \mathrm{bp}$ & 59 & 33 \\
\hline
\end{tabular}

MAGE: Melanoma antigen-encoding gene; hTERT: human telomerase reverse transcriptase; GAPDH: glyceraldehyde-3-phosphate dehydrogenase; OF: outer forward; OR: outer reverse; IF: inner forward; IR: inner reverse.

cancer and gastric cancer cells isolated from cancer patients using CRC. J2 embryonic fibroblasts were kindly donated from the Georgetown University Medical Center (GUMC). Six, 12, 25, 50, 500 and 5,000 cells of the three cell types were incubated for 4 weeks in the CRC condition. The CRC condition was prepared using the same protocols of the GUMC (15).

Patient samples. Five $\mathrm{ml}$ of blood were obtained from each of the 81 cancer patients. The patients had been admitted at Daegu Catholic University Medical Center (Daegu, Korea) and diagnosed with gastric or colorectal cancer radiographically and pathologically. The 81 patients comprised 56 colorectal cancer and 25 gastric cancer patients. The stage of gastric and colorectal cancer was determined according to the American Joint Committee on Cancer $7^{\text {th }}$ edition. Informed consent was obtained from each patient. The study protocol was approved by the Institutional Review Board (IRB) of Daegu Catholic University Medical Center. To collect CTCs from the blood specimens, red blood cells were lysed using RBC lysis buffer (Roche, Basel, Switzerland) and blood mononuclear cells were collected.

CRC culture and RNA extraction from the culture plates. The collected mononuclear cells were incubated for 4 weeks at $37^{\circ} \mathrm{C}$ in the CRC condition. Briefly, Swiss-3T3-J2 mouse fibroblasts were cultured to generate feeder cells and then, the isolated mononuclear cells were plated in F medium containing J2 feeder cells and Y-27632 (cat. no. 270-333M025, Enzo Life Sciences, Lausen, Switzerland). F medium was made by mixing Dulbecco's modified Eagle's medium (DMEM) (Invitrogen, Gaithersburg, MD, USA), 5\% fetal bovine serum (Gibco; Thermo Fisher Scientific Inc., Waltham, MA, USA), L-glutamine (Gibco), penicillin/streptomycin mix (Gibco), F12 nutrient mix (Gibco), $25 \mathrm{ng} / \mathrm{ml}$ hydrocortisone (Sigma-Aldrich, St. Louis, MO, USA), $0.125 \mathrm{ng} / \mathrm{ml}$ epidermal growth factor (EGF) (Invitrogen), $5 \mu \mathrm{g} / \mathrm{ml}$ insulin (Sigma-Aldrich), $250 \mathrm{ng} / \mathrm{ml}$ amphotericin B (Gibco), $10 \mu \mathrm{g} / \mathrm{ml}$ gentamicin (Gibco) and $0.1 \mathrm{nM}$ cholera toxin (Sigma-Aldrich). All cells were maintained at $37^{\circ} \mathrm{C}$ in a cell culture incubator with $95 \%$ humidity and $5 \% \mathrm{CO}_{2}$. At the end of incubation, some colonies, cell aggregations, $\mathrm{J} 2$ cells or unknown cells persisted on the plate. All 81 samples were treated with $1 \mathrm{ml}$ Trizol (Invitrogen), RNA was extracted, and RNA quality and quantity were measured using a spectrophotometer (NanoDrop Technologies, Wilmington, DE, USA).
Real time RT-PCR. The mRNAs of hTERT and MAGE A1-6 were amplified to determine the identity of the cultured cells. The mRNA of glyceraldehyde-3-phosphate dehydrogenase (GAPDH) was amplified to confirm the RNA integrity for all specimens. The hTERT and MAGE A1-6 mRNAs were amplified with nested PCR, whereas GAPDH mRNA was amplified with a single round of PCR amplification, using specific primers for each gene and the PCR conditions presented in Table I. Cells were determined as cancer cells if they expressed one cancer related mRNA. The amplification of all mRNAs was performed using the LightCycler 480 (Roche, Basel, Switzerland). We interpreted the PCR products as positive results using fluorescent signals and melting temperature analysis.

STR (short tandem repeat) analysis of culture cells and cancer tissue. To verify the cultured cell, we used STR analysis. In one colorectal cancer patient, some cells proliferated to form a colony (CR1520). We extracted DNA using the remnant of RNA extraction procedure and STR markers were analyzed using PowerPlex 16 system (Promega, Madison, WI, USA) with ABI 3500xL Genetic Analyzer (Applied Biosystems, Waltham, MA, USA). The matched cancer tissue of CR1520 obtained from the biopsy was also used for the STR analysis.

IRB approval and statistical analysis. This study was conducted in accordance with the standards of the Declaration of Helsinki and was approved by the IRB of Daegu Catholic University Medical Center (CR-16-002-L). All patients have provided written informed consent for their information to be stored and used in the hospital database.

For the statistical analysis, Chi-squared test was performed using MedCalc Version 14.12.0 (Ostend, Belgium).

\section{Results}

Sensitivity of CRC culture. Sensitivity data of spiked cancer cells cultured in the CRC condition are summarized in Table II. Gastric cancer cells were cultured from 6 to 5,000 cells, and colorectal cancer cells were cultured from 25 to 5,000 cells. Interestingly, even the lowest number of gastric cancer cells (6) grew in culture. 
Table II. Sensitivity of cancer cell culture using conditionally reprogrammed cell method.

\begin{tabular}{lcccccc}
\hline & \multicolumn{6}{c}{ Culture result by cell number } \\
\cline { 2 - 7 } Cell types & 6 & 12 & 25 & 50 & 500 & 5000 \\
\hline SNU 484 & + & + & + & + & + & + \\
Colorectal cancer & - & - & + & + & + & + \\
Gastric cancer & + & + & + & + & + & + \\
\hline
\end{tabular}

Clinical data, CRC culture and RT-PCR results. Demographic data of cancer patients are summarized in Table III. Most gastric cancer patients were stage I and II, while colorectal cancer patients were stage II and III.

After 4 weeks of incubation, some cells were cultured in 38 of 81 blood samples. The cultured cells were observed as colonies, cell aggregations, J2 cells and unknown cells. Figure 1 shows the cultured colonies of gastric and colorectal cancer. Among the 38 cells, 13 cells showed positive results with MAGE A1-6 or hTERT RT-PCR analysis. The overall positive rates were $16.0 \%$ for $h T E R T$ and $4.9 \%$ for $M A G E$ A1-6. The respective positive rates for each mRNA were $16.1 \%$ and $5.4 \%$ in colorectal cancer, and $16.0 \%$ and $4.0 \%$ in gastric cancer, respectively (Table III). All MAGE A1-6 positive cases were also positive for $h T E R T$ RT-PCR.

STR analysis and cancer cell determination. In the STR analysis, 16 STR markers of CR1520 were completely consistent with those of cancer tissue (Figure 2), demonstrating that the cultured cells were derived from the cancer tissue. We determined the 13 cultured cells as cancer cells based on the results of $h T E R T$ or MAGE A1-6 RT-PCR and STR analysis.

The positive rates of hTERT and MAGE Al-6 RT-PCR according to cancer stages. The association of RT-PCR positive cases with cancer stages were also analyzed (Table IV). Though the positive rates of RT-PCR were not statistically significantly associated with cancer stage, the positive rates of $h T E R T$ and MAGE RT-PCR were associated with increased cancer stage. The hTERT RT-PCR was the most efficient in identifying cancer cells in the CRC culture.

\section{Discussion}

CTCs are rare in the blood. Many methods have been used to increase CTC capture rates. These include immunomagnetic separation (22), microfluidic separation (23), microfiltration (24), electrophoresis (25), and acoustophoresis (26). Bobek et al. (27) and Zhang et al. (10) reported $66.7 \%$ and $73.7 \%$ detection rates from pancreatic and lung cancer patients,
Table III. Demographic data and circulating tumor cell culture results.

\begin{tabular}{lccc}
\hline Classifications & $\begin{array}{c}\text { Colorectal } \\
\text { cancer }\end{array}$ & $\begin{array}{c}\text { Gastric } \\
\text { cancer }\end{array}$ & Total \\
\hline Number & 56 & 25 & 81 \\
Age (Mean \pm SD) & $68.4 \pm 11.8$ & $64.8 \pm 13.6$ & $67.3 \pm 12.4$ \\
Male:Female & $35: 21$ & $17: 8$ & $52: 29$ \\
Cancer Stage & \multicolumn{4}{|c}{} \\
$\quad$ Stage I & 10 & 13 & 23 \\
Stage II & 22 & 5 & 37 \\
Stage III & 20 & 6 & 26 \\
Stage IV & 4 & 1 & 5 \\
\hline CTC culture & \multicolumn{3}{c}{$\mathrm{N}$ of Positive $(\%)$} \\
\hline Visible cells & $23(41.1)$ & $15(60.0)$ & $38(46.9)$ \\
Colony formation & $3(5.3)$ & $2(8.0)$ & $5(6.2)$ \\
hTERT RT-PCR & $9(16.1)$ & $4(16.0)$ & $13(16.0)$ \\
MAGE RT-PCR & $3(5.4)$ & $1(4.0)$ & $4(4.9)$ \\
hTERT or MAGE RT-PCR & $9(16.1)$ & $4(16.0)$ & $13(16.0)$ \\
\hline
\end{tabular}

respectively. Zhang et al. (10) successfully isolated CTCs from 14 of 19 early-stage lung cancer patients using a microfluidic three-dimensional co-culture system.

In this study, we did not use any special CTC isolation kit and culture device. We collected mononuclear cells after red blood cells lysis without the depletion of CD45 positive leukocytes to avoid cancer cell loss. The collected cells were inoculated into the CRC culture plate using a fibroblast feeder layer. The CRC culture system effectively supports the growth of normal and tumor cells of epithelial origin $(15,28)$.

We evaluated the sensitivity of the CRC culture method. In a prior study (15), the minimum number of primary keratinocytes capable of forming a colony was four. Presently, the minimum number was similar (six) but the cell number depended on the cell type. The results indicate the potential of the CRC culture method for the study of CTCs.

To determine whether the cultured cells were cancer cells, we assayed for MAGE and hTERT mRNA. Though the hTERT mRNA might be expressed in the cells of the CRC culture (15), its expression could differentiate human cancer cells from mouse fibroblast $\mathrm{J} 2$ cells. The results regarding $M A G E$ mRNA revealed that this gene is a cancer specific oncogene $(17,29)$.

The CRC method allowed the growth of some cells from the 38 blood samples. Among them, 13 samples showed the expression of MAGE or hTERT mRNA. Using RT-PCR, the $h T E R T$ mRNA was more frequently amplified than the $M A G E$ A1-6 mRNA. The general expression rates of $h T E R T$ and MAGE A mRNA in cancer cells were $85 \%$ (30) and $50 \%$ (31), respectively. This could explain the difference in RTPCR positive rates between hTERT and MAGE A1-6 


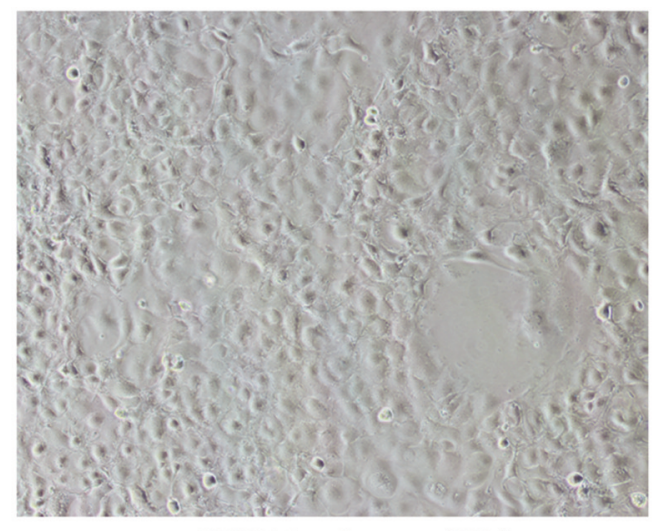

CR1554 Gastric cancer (100x)

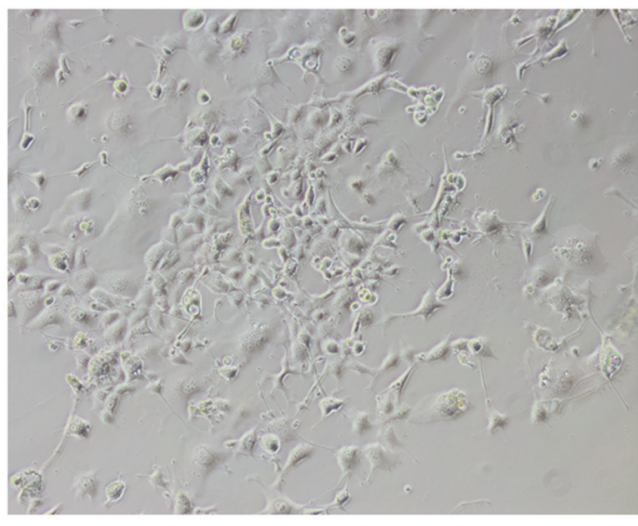

CR1556 Colorectal cancer (100x)

Figure 1. Light microscopic images of CR1554 and CR1556 cancer cells using conditionally reprogrammed cell culture.

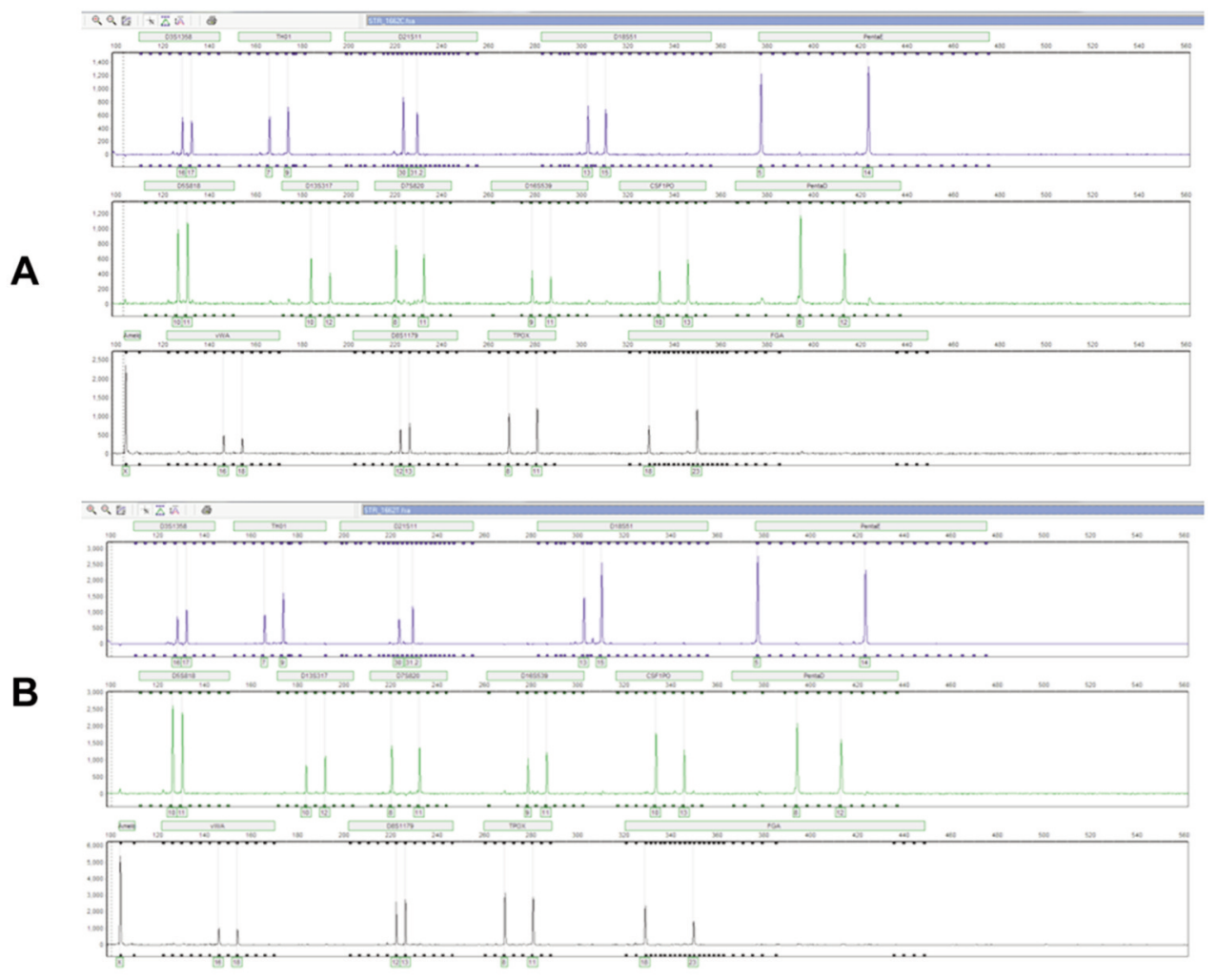

Figure 2. STR marker analysis of CR1520 disclosed the same pattern between cultured cell (A) and cancer tissue (B).

mRNAs. The hTERT mRNA expressed in all cancer cells and its positive rates were dependent on cancer stage. Therefore, hTERT RT-PCR might be the best marker for the identification of cancer cells in the CRC culture.

After one-year follow-up of the 13 patients with a positive culture, two had multiple metastases (CR1554 and CR1560) and four had metastases to adjacent organs (CR 1600,
CR1577, CR1546 and CR1632). Further studies are necessary to evaluate the clinical utility of CRC culture.

In the one case of positive culture, we isolated the tumor DNA from remnant of RNA extraction and analyzed the STR markers. In the CRC specimens, we could analyze DNA, RNA and protein levels. The CRC specimens can provide most of the information needed for cancer research. 
Table IV. Positive rates of RT-PCR results by cancer stage.

\begin{tabular}{lcccc}
\hline & Stage 1 & Stage 2 & Stage 3-4 & $p$-Value $^{\mathrm{a}}$ \\
\hline Number & 23 & 27 & 31 & \\
hTERT RT-PCR & $2(8.7)$ & $3(11.1)$ & $8(25.8)$ & 0.165 \\
MAGE RT-PCR & $0(0.0)$ & $1(3.7)$ & $3(9.7)$ & 0.251 \\
\hline
\end{tabular}

${ }^{\mathrm{a} C h i-s q u a r e d}$ test.

Therefore, the CRC culture might be the best method to study the metastatic event of cancer cells in the circulation.

The absence of a control group for comparison is a limitation of this study. The majority of circulating tumor cell studies using peripheral blood samples of cancer patients have not used a control group (27).

In summary, to isolate CTCs, we cultured blood cells of 81 cancer patients using the CRC culture method. The 38 cases displayed visible cells after 4 weeks. We characterized the culture cells using RT-PCR to detect hTERT and MAGE A1-6 mRNA. Of these, 13 cases showed cancer cell growth. Our study proved the potential of CRC culture to detect CTCs.

\section{Conflicts of Interest}

All Authors have no conflicts of interest to declare regarding this study.

\section{Authors' Contributions}

Chun-Seok Yang and Dae-Dong Kim collected blood samples and clinical information from the patients of colorectal cancer. In-Hwan Kim and Hyun-Dong Chae collected blood samples and clinical information from the patients of colorectal cancer. Chun-Seok Yang wrote the article. Chang-Ho Jeon performed the entire experiment, collected the experimental data, and revised the version to be submitted. All Authors designed the concept of this study and analyzed the experimental results.

\section{Acknowledgements}

Supported by Basic Science Research Program through the National Research Foundation of Korea (NRF) funded by the Ministry of Education, Science and Technology (NRF-2013R1A1A2007189).

\section{References}

1 Ferreira MM, Ramani VC and Jeffrey SS: Circulating tumor cell technologies. Mol Oncol 10(3): 374-394, 2016. PMID: 26897752. DOI: 10.1016/j.molonc.2016.01.007.

2 Ilie M, Szafer-Glusman E, Hofman V, Long-Mira E, Suttmann R, Darbonne W, Butori C, Lalvée S, Fayada J, Selva E, Yu W, Marquette CH, Shames DS, Punnoose E and Hofman P: Expression of MET in circulating tumor cells correlates with expression in tumor tissue from advanced-stage lung cancer patients. Oncotarget 8(16): 26112-26121, 2017. PMID: 28212540. DOI: $10.18632 /$ oncotarget.15345

3 Masuda T, Hayashi N, Iguchi T, Ito S, Eguchi H and Mimori K: Clinical and biological significance of circulating tumor cells in cancer. Mol Oncol 10(3): 408-417, 2016. PMID: 26899533. DOI: $10.1016 /$ j.molonc.2016.01.010

4 Szilágyi M, Pös O, Márton É, Buglyó G, Soltész B, Keserú J, Penyige A, Szemes T and Nagy B: Circulating cell-free nucleic acids: Main characteristics and clinical application. Int J Mol Sci 21(18): 6827, 2020. PMID: 32957662. DOI: 10.3390/ijms21186827

5 Stewart CM and Tsui DWY: Circulating cell-free DNA for noninvasive cancer management. Cancer Genet 228-229: 169-179, 2018. PMID: 29625863. DOI: 10.1016/j.cancergen.2018.02.005

6 Jiang T, Ren S and Zhou C: Role of circulating-tumor DNA analysis in non-small cell lung cancer. Lung Cancer 90(2): 128134, 2015. PMID: 26415994. DOI: 10.1016/j.lungcan.2015.09.013

7 Brock G, Castellanos-Rizaldos E, Hu L, Coticchia C and Skog $\mathrm{J}$ : Liquid biopsy for cancer screening, patient stratification and monitoring. Transl Cancer Res 4(3): 280-290, 2015. DOI: 10.3978/j.issn.2218-676X.2015.06.05

8 Kolostova K, Zhang Y, Hoffman RM and Bobek V: In vitro culture and characterization of human lung cancer circulating tumor cells isolated by size exclusion from an orthotopic nude-mouse model expressing fluorescent protein. J Fluoresc 24(5): 1531-1536, 2014. PMID: 25141982. DOI: 10.1007/s10895-014-1439-3

9 Halo TL, McMahon KM, Angeloni NL, Xu Y, Wang W, Chinen AB, Malin D, Strekalova E, Cryns VL, Cheng C, Mirkin CA and Thaxton CS: NanoFlares for the detection, isolation, and culture of live tumor cells from human blood. Proc Natl Acad Sci U S A 111(48): 1710417109, 2014. PMID: 25404304. DOI: 10.1073/pnas.1418637111

10 Zhang Z, Shiratsuchi H, Lin J, Chen G, Reddy RM, Azizi E, Fouladdel S, Chang AC, Lin L, Jiang H, Waghray M, Luker G, Simeone DM, Wicha MS, Beer DG, Ramnath N and Nagrath S: Expansion of CTCs from early stage lung cancer patients using a microfluidic co-culture model. Oncotarget 5(23): 12383-12397, 2014. PMID: 25474037. DOI: 10.18632/oncotarget.2592

11 Kolostova K, Matkowski R, Gürlich R, Grabowski K, Soter K, Lischke R, Schützner J and Bobek V: Detection and cultivation of circulating tumor cells in gastric cancer. Cytotechnology 68(4): 1095-1102, 2016. PMID: 25862542. DOI: 10.1007/s10616-0159866-9

12 Li Y, Zhang X, Ge S, Gao J, Gong J, Lu M, Zhang Q, Cao Y, Wang DD, Lin PP and Shen L: Clinical significance of phenotyping and karyotyping of circulating tumor cells in patients with advanced gastric cancer. Oncotarget 5(16): 65946602, 2014. PMID: 25026283. DOI: 10.18632/oncotarget.2175

13 Grillet F, Bayet E, Villeronce O, Zappia L, Lagerqvist EL, Lunke S, Charafe-Jauffret E, Pham K, Molck C, Rolland N, Bourgaux JF, Prudhomme M, Philippe C, Bravo S, Boyer JC, Canterel-Thouennon L, Taylor GR, Hsu A, Pascussi JM, Hollande F and Pannequin J: Circulating tumour cells from patients with colorectal cancer have cancer stem cell hallmarks in ex vivo culture. Gut 66(10): 1802-1810, 2017. PMID: 27456153. DOI: 10.1136/gutjnl-2016-311447

14 Kaifi JT, Kunkel M, Dicker DT, Joude J, Allen JE, Das A, Zhu J, Yang Z, Sarwani NE, Li G, Staveley-O'Carroll KF and ElDeiry WS: Circulating tumor cell levels are elevated in colorectal cancer patients with high tumor burden in the liver. Cancer Biol Ther 16(5): 690-698, 2015. PMID: 25785486. DOI: 10.1080/15384047.2015.1026508 
15 Liu X, Ory V, Chapman S, Yuan H, Albanese C, Kallakury B, Timofeeva OA, Nealon C, Dakic A, Simic V, Haddad BR, Rhim JS, Dritschilo A, Riegel A, McBride A and Schlegel R: ROCK inhibitor and feeder cells induce the conditional reprogramming of epithelial cells. Am J Pathol 180(2): 599-607, 2012. PMID: 22189618. DOI: 10.1016/j.ajpath.2011.10.036

16 Sang M, Wu X, Fan X, Sang M, Zhou X and Zhou N: Multiple MAGE-A genes as surveillance marker for the detection of circulating tumor cells in patients with ovarian cancer. Biomarkers 19(1): 34-42, 2014. PMID: 24320162. DOI: 10.3109/1354750X.2013.865275

17 Joosse SA, Müller V, Steinbach B, Pantel K and Schwarzenbach $\mathrm{H}$ : Circulating cell-free cancer-testis MAGE-A RNA, BORIS RNA, let-7b and miR-202 in the blood of patients with breast cancer and benign breast diseases. Br J Cancer 111(5): 909-917, 2014. PMID: 24983365. DOI: $10.1038 /$ bjc.2014.360.

18 Jheon S, Hyun DS, Lee SC, Yoon GS, Jeon CH, Park JW, Park CK, Jung MH, Lee KD and Chang HK: Lung cancer detection by a RT-nested PCR using MAGE A1-6 common primers. Lung Cancer 43(1): 29-37, 2004. PMID: 14698534. DOI: 10.1016/j.lungcan.2003.08.014

19 Kwon S, Kang SH, Ro J, Jeon CH, Park JW and Lee ES: The melanoma antigen gene as a surveillance marker for the detection of circulating tumor cells in patients with breast carcinoma. Cancer 104(2): 251-256, 2005. PMID: 15937912. DOI: $10.1002 / \mathrm{cncr} .21162$

20 Ping B, Tsuno S, Wang X, Ishihara Y, Yamashita T, Miura K, Miyoshi F, Shinohara Y, Matsuki T, Tanabe Y, Tanaka N, Ogawa $\mathrm{T}$, Shiota $\mathrm{G}$ and Miura N: Comparative study of ${ }^{18} \mathrm{~F}-\mathrm{FDG}-$ PET/CT imaging and serum hTERT mRNA quantification in cancer diagnosis. Cancer Med 4(10): 1603-1611, 2015. PMID: 26275387. DOI: $10.1002 / \mathrm{cam} 4.508$

21 Chebel A, Rouault JP, Urbanowicz I, Baseggio L, Chien WW, Salles G and Ffrench M: Transcriptional activation of hTERT, the human telomerase reverse transcriptase, by nuclear factor of activated T cells. J Biol Chem 284(51): 35725-35734, 2009. PMID: 19843528. DOI: 10.1074/jbc.M109.009183

22 Andreopoulou E, Yang LY, Rangel KM, Reuben JM, Hsu L, Krishnamurthy S, Valero V, Fritsche HA and Cristofanilli M: Comparison of assay methods for detection of circulating tumor cells in metastatic breast cancer: AdnaGen AdnaTest BreastCancer Select/Detect ${ }^{\mathrm{TM}}$ versus Veridex CellSearch ${ }^{\mathrm{TM}}$ system. Int J Cancer 130(7): 1590-1597, 2012. PMID: 21469140. DOI: $10.1002 /$ ijc.26111

23 Galletti G, Sung MS, Vahdat LT, Shah MA, Santana SM, Altavilla G, Kirby BJ and Giannakakou P: Isolation of breast cancer and gastric cancer circulating tumor cells by use of an anti HER2-based microfluidic device. Lab Chip 14(1): 147-156, 2014. PMID: 24202699. DOI: 10.1039/c31c51039e
24 Kolostova K, Cegan M and Bobek V: Circulating tumour cells in patients with urothelial tumours: Enrichment and in vitro culture. Can Urol Assoc J 8(9-10): E715-E720, 2014. PMID: 25408812. DOI: $10.5489 /$ cuaj.1978

25 Peeters DJ, De Laere B, Van den Eynden GG, Van Laere SJ, Rothé F, Ignatiadis M, Sieuwerts AM, Lambrechts D, Rutten A, van Dam PA, Pauwels P, Peeters M, Vermeulen PB and Dirix LY: Semiautomated isolation and molecular characterisation of single or highly purified tumour cells from CellSearch enriched blood samples using dielectrophoretic cell sorting. Br J Cancer 108(6): 1358-1367, 2013. PMID: 23470469. DOI: 10.1038/bjc.2013.92

26 Antfolk M, Antfolk C, Lilja H, Laurell T and Augustsson P: A single inlet two-stage acoustophoresis chip enabling tumor cell enrichment from white blood cells. Lab Chip 15(9): 2102-2109, 2015. PMID: 25824937. DOI: 10.1039/c5lc00078e

27 Bobek V, Gurlich R, Eliasova P and Kolostova K: Circulating tumor cells in pancreatic cancer patients: enrichment and cultivation. World J Gastroenterol 20(45): 17163-17170, 2014. PMID: 25493031. DOI: 10.3748/wjg.v20.i45.17163

28 Suprynowicz FA, Upadhyay G, Krawczyk E, Kramer SC, Hebert JD, Liu X, Yuan H, Cheluvaraju C, Clapp PW, Boucher RC Jr, Kamonjoh CM, Randell SH and Schlegel R: Conditionally reprogrammed cells represent a stem-like state of adult epithelial cells. Proc Natl Acad Sci U S A 109(49): 20035-20040, 2012. PMID: 23169653. DOI: 10.1073/pnas.1213241109

29 Szatanek R, Drabik G, Baran J, Kolodziejczyk P, Kulig J, Stachura J and Zembala M: Detection of isolated tumour cells in the blood and bone marrow of patients with gastric cancer by combined sorting, isolation and determination of MAGE-1, -2 mRNA expression. Oncol Rep 19(4): 1055-1060, 2008. PMID: 18357396.

30 Ivancich M, Schrank Z, Wojdyla L, Leviskas B, Kuckovic A, Sanjali A and Puri N: Treating cancer by targeting telomeres and telomerase. Antioxidants (Basel) 6(1): 15, 2017. PMID: 28218725. DOI: 10.3390/antiox6010015

31 Kerkar SP, Wang ZF, Lasota J, Park T, Patel K, Groh E, Rosenberg SA and Miettinen MM: MAGE-A is more highly expressed than NY-ESO-1 in a systematic immunohistochemical analysis of 3668 cases. J Immunother 39(4): 181-187, 2016. PMID: 27070449. DOI: 10.1097/CJI.0000000000000119

Received January 8, 2021

Revised February 25, 2021 Accepted February 26, 2021 